\title{
POLITIK HUKUM PENGELOLAAN KAWASAN PERBATASAN (STUDI KASUS BADAN PENGELOLA PERBATASAN PROVINSI KEPULAUAN RIAU)
}

\author{
Okky Razma \\ Alumni Program Studi IImu Hukum Fakultas IImu Sosial dan IImu Politik \\ Universitas Maritim Raja Ali Haji \\ Email : okkyrazma07@gmail.com \\ Pery Rehendra Sucipta \\ Program Studi IImu Hukum Fakultas IImu Sosial dan IImu Politik \\ Universitas Maritim Raja Ali Haji \\ Email : perysucipta@gmail.com
}

\begin{abstract}
Indonesia is an archipelagic country, the extent of Indonesia and islands spread across Indonesia. Indonesia is bordered by many countries, it means that Indonesia has many border areas. The border area is a strategic area in maintaining the area, therefore it is necessary to manage the border area. The institutional landscape that takes place in the provincial governance of the Riau Archipelago is part of the legal politics that has added complex complexity. Therefore, the authors to conduct further research on the Bureau of Political law of Border Area Management (Case Study of Border Planning Board of Riau Islands Province). This research was conducted with empirical juridical approach, with secondary data and primary data, then data collected descriptively. The result of this study is that the objectives of the political law can be achieved.
\end{abstract}

Keywords: Political Law, Border Area.

\begin{abstract}
Abstrak
Indonesia adalah negara kepulauan, luasnya negara Indonesia dan banyaknya pulau yang tersebar di Indonesia mengakibatkan Indonesia berbatasan dengan banyak negara, itu artinya Indonesia memiki banyak kawasan perbatasan. Kawasan perbatasan merupakan kawasan strategis dalam menjaga integritas wilayah negara oleh karena itu diperlukan pengelolaan terhadap kawasan perbatasan. Dimanika kelembagaan yang terjadi pada pengelolaan kawasan perbatasan daerah provinsi kepulauan riau merupakan bagian dari politik hukum pemerintah yang ternyata menambah kompleksitas permasalahan yang telah kompleks. Oleh karena itu penulis tertarik untuk melakukan penelitian lebih lanjut dengan tujuan untuk mengetahui Bagaiamana Politik Hukum Pengelolaan Kawasan Perbatasan (Studi Kasus Badan Pengelola Perbatasan Provinsi Kepulauan Riau). Penelitian ini dilakukan dengan pendekatan yuridis empiris, dengan sumber data sekunder dan data primer, selanjutnya data yang diperoleh dianalisis secara kualitatif kemudian dipaparkan secara deskriptif. Hasil dari penelitian ini adalah diperlukannya perbaikan terhadap arah politik hukum pemerintah yang mengarah kepada penguatan kelembagaan terhadap Badan Pengelola Perbatasan agar tujuan dari politik hukum itu sendiri dapat tercapai.
\end{abstract}

Kata Kunci : Politik Hukum, Kawasan Perbatasan. 


\section{Pendahuluan}

\subsection{Latar Belakang Masalah}

Indonesia adalah negara kepulauan (Archipelago State), Luas laut Indonesia sebesar dua pertiga dari luas Indonesia $\pm 3.273 .810 \mathrm{~km}^{2}$ menjadikan Indonesia sebagai Negara kepulauan terluas didunia. ${ }^{1}$ Wilayah negara Indonesia yang luas dan terdiri dari banyak pulau mengakibatkan Indonesia bertetangga dengan banyak negara, itu artinya Indonesia memiliki banyak kawasan perbatasan baik perbatasan laut maupun perbatasan darat. Berdasarkan Pasal 1 Angka (6) bahwasannya kawasan perbatasan didefinisikan sebagai bagian dari wilayah negara yang terletak pada sisi dalam sepanjang batas wilayah Indonesia dengan negara lain. ${ }^{2}$ Batas-batas wilayah suatu negara menempati posisi yang penting dilihat dari aspek geografis, hukum maupun politis.

Kawasan perbatasan merupakan kawasan strategis dalam menjaga integritas wilayah negara. Kenyataannya kawasan yang dianggap strategis dan penting tersebut justru keadaannya sangat memprihatinkan dan jauh dari sentuhan pemerintah. Permasalahan kawasan perbatasan yang sangat kompleks dalam penanganannya tentu memerlukan kehadiran negara melalui organisasi kenegaraan untuk mewujudkan tujuan negara yaitu kesejahteraan yang khususnya bagi kawasan perbatasan.

Salah satu wilayah Negara Indonesia yang terletak di perbatasan adalah Provinsi Kepulauan Riau. Provinsi Kepulauan Riau dapat dikatakan sebagai miniatur dari Negara Indonesia. Wilayah Provinsi Kepulauan Riau hampir Sembilan puluh enam persen (96\%) berupa lautan, sementara daratan hanya empat persen (4\%). Secara geografis, Kepulauan Riau berbatasan langsung dengan tiga negara tetangga, Malaysia, Singapura, dan Vietnam. Kepulauan Riau berada di wilayah paling utara dari kawasan Indonesia bagian barat, yang memiliki sekitar 1.795 (seribu tujuh ratus Sembilan puluh lima) pulau yang berada di garis perbatasan langsung dengan negara tetangga. ${ }^{3}$ Dari jumlah pulau tersebut diatas, 22 (dua puluh dua) diantaranya termasuk pulau terdepan Indonesia yang berbatasan langsung dengan negara lain. Jumlah kawasan perbatasan di Provinsi Kepulauan Riau yang cukup banyak ternyata sebanding dengan banyaknya masalah perbatasan di provinsi ini antara lain: 4

Permasalahan penegasan batas dengan negara tetangga. Kondisi keamanan sangat rawan (berada di jalur pelayaran internasional, penyelundupan) Jaringan telekomunikasi belum merata, Terbtasnya sarana perhubungan, Aktifitas ekonomi dan sosial tergangung kondisi alam, Eksploitasi sumber daya alam (illegal fishing, penambangan illegal) Kurangnya infrastruktur dasar wilayah (jalan, sarana transportasi,energi, air bersih) dan infrastruktur sosial dasar (kesehatan, pendidikan, perumahan), Masih diperlukannya Ketersediaan Infrastruktur Pemerintahan, terutama untuk daerah-daerah perbatasan (Kecamatan/Desa) yang mengalami pemekaran.

Mengingat kawasan perbatasan merupakan

1 Adhayanto, Oksep (2014), Maritime Constitution. Jurnal selat. Vol 2, Oktober. hlm. 140

2 Pasal 1 angka (6) Undang-Undang Nomor 43 Tahun 2008 Tentang Wilayah Negara.

3 Panama, A. N. (2012). Menjaga Indonesia Dari Kepri. Tanjungpinang: Badan Pengelola Perbatasan Provinsi Kepri. hlm. 44.

4 Diskusi IImiah Labor Administrasi Negara dengan tema "Kebijakan Percepatan Pengembangan Kawasan Perbatasan Kepulauan Riau" yang disampaikan oleh Drs. Edy Sofyan, M.Si pada tanggal 19 November 2015. 
Kawasan strategis dalam menjaga keutuhan Wilayah Negara maka diperlukan pengaturan secara tersendiri dalam Undang-Undang. Pengaturan Batas Wilayah Negara dimaksudkan untuk memberikan kepastian hukum mengenai Wilayah Negara, kewenangan pengelolaan Wilayah Negara, dan hakhak berdaulat. ${ }^{5}$ Berdasarkan hal tersebut Pemerintah mengambil peran lewat Undang- Undang Nomor 43 Tahun 2008 Tentang wilayah negara yang salah satu amatnya yaitu untuk segera dibentuk sebuah lembaga yang berwenang dalam mengelola kawasan perbatasan. Pada Tahun 2010, lewat Peraturan Presiden Nomor 12 Tahun 2010 dibentuk Badan Nasional Pengelola Perbatasan (BNPP) yang merupakan sebuah lembaga yang berkedudukan di bawah dan bertanggungjawab kepada presiden.

Pelaksanakan tugas dan fungsi BNPP dibantu oleh Badan Pengelola Perbatasan di daerah (BPPD). Hal ini karena persoalan perbatasan bukan hanya tanggungjawab pemerintah pusat tetapi juga pemerintah daerah. Pedoman pembentukan BPPD diatur dalam Peraturan Menteri Dalam Negeri Nomor 2 Tahun 2011 Tentang Pedoman Pembentukan Badan Pengelola Perbatasan di Daerah. BPP Provinsi Kepulauan Riau dibentuk melalui Peraturan Daerah Nomor 5 Tahun 2011 tentang Organisasi Dan Tata Kerja Inspektorat, Badan Perencanaan Pembangunan Daerah, Lembaga Teknis Daerah, Satuan Polisi Pamong Praja Dan Lembaga Lain Provinsi Kepulauan Riau. Provinsi Kepulauan Riau memiliki 41 Lokasi Prioritas (LOKPRI) Berdasarkan Rencana Induk (Rinduk) Badan Nasional Pengelola Perbatasan (BNPP) Tahun 2015-2019 (Perka Bnpp No. 1 Tahun 2015).
Sedemikian banyaknya daerah yang menjadi Lokasi Prioritas yang disertai dengan permasalahan kawasan perbatasan yang beragam di Provinsi Kepulauan Riau tentunya memerlukan kerja keras serta komitmen dalam penyelesaiannya. Pada Tahun 2014 terjadi perubahan terhadap Undang-Undang Pemerintahan Daerah yang berimplikasi kepada kelembagaan BPP Provinsi Kepulauan Riau, di dalam Pasal 231 Undang-Undang Nomor 23 Tahun 2014 Tentang Pemerintahan Daerah mengamatkan bahwa pembentukan lembaga tertentu di daerah yang di atur oleh peraturan perundang-undangan dijadikan bagian dari perangkat daerah, dengan dasar ini dan beberapa peraturan lanjutannya maka BPP Provinsi Kepulauan Riau beralih fungsi kepada Biro Pemerintahan dan Perbatasan.

Permasalahan yang ada di kawasan perbatasan merupakan masalah yang mengkhawatirkan serta penting untuk segera ditangani, terlebih lagi terdapat banyak kendala dalam penanganan masalahnya. Saat BPPD sedang berupaya menyelesaikan satu per satu masalah kawasan perbatasan, pemerintah lewat peraturan baru yang mengubah Kelembagaan BPPD menjadi biro seolah menambah kompleksitas permasalahan perbatasan. Akankan efektif ketika ditangani oleh perangkat daerah setingkat biro yang mengubah Kelembagaan BPPD menjadi biro seolah menambah kompleksitas permasalahan perbatasan. Akankan efektif ketika ditangani oleh perangkat daerah setingkat biro yang kewenangannya lebih sedikit dari lembaga setingkat Badan, terlebih lagi bagi Provinsi Kepulauan Riau yang memiliki 41 LOKPRI.

Semangat Pengelolaan Kawasan Perbata-

5 Penjelasan Undang-Undang Nomor 43 Tahun 2008 Tentang Wilayah Negara 
san seolah bangkit kembali dibuktikan dengan dibentuknya Peraturan Menteri Dalam Negeri Nomor 140 Tahun 2017 tentang Pembentukan Badan Pengelola Perbatasan di Daerah. BPPD yang tadinya dibentuk lalu diubah menjadi Biro dan saat ini dibentuk kembali dengan Kewenangan yang serupa.

Faktor apa yang mendorong pemerintah merubah BPPD menjadi Biro ditengah isu permasalahan serta kendala terkait pengelolaan perbatasan yang cukup banyak khususnya di Provinsi Kepulauan Riau serta membentuk kembali BPPD. Bagaimana sebenarnya arah kebijakan pemerintah (politik hukum) terkait pengelolaan kawasan perbatasan. Hal ini yang membuat penulis tertarik untuk melakukan penelitian dengan judul "Politik Hukum Pengelolaan Kawasan Perbatasan (Studi Kasus Badan Pengelola Perbatasan Provinsi Kepulauan Riau).

\subsection{Rumusan Masalah}

Bagaimana Politik Hukum Pengelolaan Kawasan Perbatasan (Studi Kasus Badan Pengelola Perbatasan Provinsi Kepulauan Riau)?

\subsection{Metode Penulisan}

a. Jenis Penelitian

Penelitian ini akan disusun dengan menggunakan tipe penelitian yuridis empiris. Pendekatan yuridis empiris yaitu cara prosedur yang dipergunakan untuk memecahkan masalah penelitian dengan meneliti data sekunder terlebih dahulu untuk kemudian dilanjutkan dengan mengadakan penelitian terhadap data primer di lapangan. ${ }^{6}$ Dalam pendekatan yuridis empiris atau yuridis sosiologis, hukum sebagai law in action, dideskripsikan sebagai gejala sosial yang empiris. Penelitian ini termasuk dalam penelitian hukum deskripsi-analitis, yaitu menggambarkan peraturan perundangundangan yang berlaku dikaitkan dengan teori-teori hukum dan praktek-praktek pelaksanaan hukum positif yang menyangkut permasalahan. ${ }^{7}$ Deskriptif karena didalam penelitian ini akan diperoleh gambaran yang menyeluruh dan sistematis tentang focus penelitian. Sedangkan analitis karena data-data yang diperoleh akan dianalisis.

b. Sumber Data

Dalam penelitian ini, data yang penulis gunakan dalam adalah data sekunder dan data primer. Data Sekunder, Data sekunder yaitu bahan pustaka yang mencakup dokumen-dokumen resmi, buku-buku perpustakaan, peraturan perundangundangan, karya ilmiah, artikel-artikel, serta dokumen yang berkaitan dengan materi penelitian. Dari bahan hukum sekunder tersebut menca kup tiga bagian, yaitu: ${ }^{8}$

Bahan Hukum Primer

Bahan hukum primer yaitu bahan-bahan hukum yang mengikat. Bahan hukum primer yang digunakan dalam penelitian ini terdiri dari peraturan perundang-undangan yaitu:

1. Undang-Undang Dasar 1945 pasal 25 A

2. Undang-Undang Nomor 23 Tahun 2014 Tentang Pemerintahan Daerah

6 Soerjono Soekanto dan Sri Mamudji. (1985). Penelitian Hukum Normatif SuatuTinjauan Singkat. Jakarta: Rajawali Pers. hlm. 52.

7 Ronny Hanitijo Soemitro. (1988). Metode Penelitian Hukum dan Jurimetri. Jakarta: Ghalia Indonesia. hlm 35 
3. Undang-Undang Dasar 1945 pasal 25 A

4. Undang-Undang Nomor 23 Tahun 2014 Tentang Pemerintahan Daerah

5. Undang-Undang Nomor 43 Tahun 2008 Tentang Wilayah Negara

6. Peraturan Presiden Republik Indonesia Nomor 12 Tahun 2010 Tentang Badan Nasional Pengelola Perbatasan

7. Peraturan Menteri Dalam Negeri Nomor 2 Tahun 2011 Tentang Pedoman Pembentukan Badan Pengelola Perbatasan Di Daerah

8. Peraturan Daerah Provinsi Kepulauan Riau Nomor 5 Tahun 2011 Tentang Organisasi Dan Tata Kerja Inspektorat, Badan Perencanaan Pembangunan Daerah, Lembaga Teknis Daerah, Satuan Polisi Pamong Praja Dan Lembagab Lain Provinsi Kepulauan Riau

9. Peraturan Pemerintah Nomor 8 Tahun 2016 Tentang Perangkat Daerah

10. Peraturan Gubernur Kepulauan Riau Nomor 60 Tahun 2016 Tedntang Kedudukan , Susunan Organisasi, Tugas Dan Fungsi, Serta Tata Kerja Perangkat Daerah

11. Peraturan Menteri Dalam Negeri Nomor 140 Tahun 2017 Tentang Pembentukan Badan Pengelola Perbatasan di Daerah

Bahan Hukum Sekunder
Bahan hukum sekunder yaitu bahan hukum yang memberikan penjelasan mengenai bahan hukum primer, seperti doktrin, jurnal, hasil-hasil penelitian, hasil karya dari kalangan hukum, dan lain-lain

Bahan Hukum Tertier

Bahan hukum tertier yakni bahan yang memberikan petunjuk maupun penjelasan terhadap hukum primer dan sekunder; seperti kamus, ensiklopedia, indeks kumulatif dan lain-lain.

Data Primer

Data Primer adalah data yang diperoleh secara langsung berupa keterangan keterangan dan pendapat dari para informan dan kenyataan-kenyataan yang ada di lapangan melalui wawancara. ${ }^{9}$

Data Primer dalam penelitian ini penulis dapatkan dari beberapa instansi terkait yaitu sebagai berikut:

1. Mantan Kepala Badan Pengelola Perbatasan Provinsi Kepulauan Riau

2. Biro Pemerintahan dan Perbatasan Provinsi Kepulauan Riau.

c. Teknik Pengumpulan Data

Penulis menggunakan dua teknik pengumpulan data didalam penelitian ini yaitu Studi Pustaka dan Studi Lapangan.

d. Analisis Data

Pada penelitian ini data yang diperoleh akan dianalisis secara deskriptif kualitatif. Analisis yang dilakukan dengan mendeskri-

8 Ibid., hlm. 13.

9 Bambang Sunggono. (2008). Metode Penelitian Hukum, Bandung: Rajawali Pers. hlm. 15. 
sikan serta menggambarkan data dan fakta yang dihasilkan dari suatu penelitian di lapangan dengan suatu interpretasi, evaluasi, dan pengetahuan umum. Analisa data dilakukan dengan menggunakan penalaran deduktif, yaitu penalaran yang dimulai dengan menelaah bahan-bahan hukum, yaitu peraturan perundangundangan, doktrin hukum, dan pendapat para ahli hukum kemudian diterapkan pada permasalahan yang diteliti sehingga dihasilkan jawaban atas permasalahan.

\section{Kajian Teoritis}

\subsection{Wilayah Perbatasan Negara}

Negara Kesatuan Republik Indonesia sebagai Negara Kepulauan yang berciri nusantara mempunyai kedaulatan atas wilayahnya serta memiliki hak-hak berdaulat di luar wilayah kedaulatannya dan kewenangan tertentu lainnya untuk dikelola dan dimanfaatkan untuk sebesarbesarnya kemakmuran rakyat. Keberadaan suatu wilayah dengan batas-batas tertentu yang jelas merupakan salah satu syarat berdirinya suatu negara. ${ }^{10}$ Wilayah NKRI berbatasan dengan 10 (sepuluh) negara yaitu India, Malaysia, Singapura, Thailand, Vietnam, Pilipina, Palau, Papua New Guinea, Australia, dan Timor Leste. ${ }^{11}$

Menurut pendapat ahli geografi politik, pengertian perbatasan dapat dibedakan menjadi dua, yaitu boundaries dan frontier. Kedua defenisi ini mempunyai arti dan makna yang berbeda meskipun keduanya saling melengkapi dan mempunyai nilai yang strategis bagi kedaulatan wilayah negara.
Perbatasan disebut frontier karena posisinya yang terletak di depan (front) atau dibelakang (hinterland) dari suatu negara. Oleh karena itu, frontier dapat juga disebut dengan istilah foreland, borderland ataupun march. Sedangkan istilah boundary digunakan karena fungsinya yang mengikat atau membatasi (bound or limit) suatu unit politik, dalam hal ini adalah negara. Semua yang terdapat di dalamnya terikat menjadi satu kesatuan yang bulat dan utuh serta saling terintegrasi satu dengan yang lain. Boundary paling tepat dipakai apabila suatu negara dipandang sebagai unit spasial yang berdaulat. ${ }^{12}$

Perbatasan dapat dikategorikan kedalam empat tipe perbatasan, yaitu: ${ }^{13}$

Alenated borderland; suatu wilayah perbatasan yang tidak terjadi aktifitas lintas batas sebagai akibat berkecamuknya perang, konflik, dominasi nasionalisme, kebencian ideologis, permusuhan, agama, perbedaan kebudayaan dan dan persaingan etnik.

Coxistent borderland; suatu wilayah perbatasan dimana konflik lintas batas bisa ditekan sampai ketingkat yang bisa dikendalikan meskipun masih muncul persoalan yang tak terselesaikan misalnya yang berkaitan dengan masalah kepemilikan sumberdaya strategis di perbatasan.

Interdependen borderland; suatu wilayah perbatasan yang kedua sisinya secara simbolik dihubungkan oleh hubungan internasional yang relatif stabil. Penduduk di kedua bagian daerah perbatasan, juga di kedua negara terlibat dalam berbagai kegiatan perekonomian yang saling menguntungkan dan kurang lebih dalam tingkat yang setara, misalnya salah satu pihak mempunyai fasili-

10 Tommy Hendra Purwaka.Tinjauan Hukum Laut Terhadap Wilayah Kesatuan Republik Indonesia. Mimbar Hukum .26 (3). hlm. 356.

11 Acmad Jusnadi, Herie Saksono dan Suryo Sakti.(2005).Platform Penanganan Permasalahan Perbatasan Antarmegara. Jakarta: Direktorat Wilayah Administrasi dan Perbatasan, Direktorat Jenderal Permasalahan Umum, Departemen Dalam Negeri. hlm..1-4

12 Suryo Sakti Hadiwijoyo. Batas Wilayah Negara Indonesia.(2008). Yogyakarta: Gava Media. hlm. 37.

13 Budi Hermawan B. (2016).Konsepsi dan Pengelolaan Wilayah Perbatasan Negara: Perspektif Hukum Internasional. Tanjungpura Law Jurnal.Vol 1. hlm. 55. 
tas produksi sementara yang lain memiliki tenaga kerja yang murah.

Integrated borderland; suatu wilayah perbatasan kegiatan yang ekonominya merupakan sebuah kesatuan, nasionalisme jauh menyurut pada kedua negara dan keduanya tergabung dalam sebuah persekutuan yang erat.

Berbicara tentang perbatasan, tidak terlepas juga dari bentuk kebijakan negara untuk mempertahankan wilayahnya. Hukum Internasional memberikan hak dan kewenangan sepenuhnya kepada masing-masing negara untuk mengatur masalah dalam negerinya sendiri, tegasnya hal-hal yang ada atau terjadi di dalam batas-batas wilayahnya. Kebijakan negara berhubungan langsung dengan kedaulatan suatu negara untuk secara bebas melakukan kegiatan sesuai dengan kepentingannya, asal kegiatan tersebut tidak bertentangan dengan hukum internasional. ${ }^{14}$ Oleh karena itu dalam hal ini pemerintah harus jeli dalam membuat kebijakan terkait kawasan perbatasan.

\subsection{Pengelolaan Kawasan Perbatasan}

Secara konstitusional pengelolaan kawasan perbatasan berlandas pada pasal 25A UndangUndang Dasar 1945. Dalam rangka mengejawantahkan maksud Undang-Undang Dasar Negara Republik Indonesia Tahun 1945 serta mengingat sisi terluar wilayah Indonesia yang disebut kawasan perbatasan merupakan kawasan strategis dalam menjaga kedaulatan negara maka diperlukan pengaturan-pengaturan kewilayahan secara nasional dan khusus terkait hal ini. ${ }^{15}$ Maka lahirlah UndangUndang 43 Tahun 2008 Tentang Wilayah Negara.

Pengaturan batas-batas Wilayah Negara dimaksudkan untuk memberikan kepastian hukum mengenai ruang lingkup wilayah negara, kewenangan pengelolaan Wilayah Negara, dan hakhak berdaulat. Dalam hal ini negara berkepentingan untuk ikut mengatur pengelolaan dan pemanfaatan di laut bebas dan dasar laut internasional sesuai dengan hukum internasional. Pemanfaatan di laut bebas dan di dasar laut meliputi pengelolaan kekayaan alam, perlindungan lingkungan laut dan keselamatan navigasi. Hal-hal pokok yang diatur dalam Undang-Undang tersebut adalah: ${ }^{16}$

Ruang lingkup Wilayah Negara yang meliputi wilayah daratan, wilayah perarian pedala man, perairan kepulauan, laut teritorial, dasar laut, dan tanah di bawahnya, serta ruang udara di atasnya termasuk seluruh sumber kekayaan yang terkandung di dalamnya.

Hak-hak berdaulat Negara Republik Indonesia di Zona Ekonomi Eksklusif dan Landas Kontinen serta hak pengawasan di Zona Tambahan.

Kewenangan Pemerintah melakukan pengaturan pengelolaan dan pemanfaatan wilayah negara serta Kawasan Perbatasan.

Kelembagaan yang diberi kewenangan untuk melakukan penanganan Kawasan Perbatasan. Unsur keanggotaan kelembagaan ini berasal dari unsur Pemerintah dan Pemerintah Daerah mengingat posisi strategis wilayah perbatasan terkait dalam hal seperti kedaulatan negara, keutuhan -

\footnotetext{
14 Boer Mauna. Hukum Internasional: Pengertian, Peranan, dan Fungsi Dalam Era Dinamika Global, edisi ke 2. (2000). Bandung: Alumni. hlm. 24

15 Penjelasan Undang-Undang Nomor 43 Tahun 2008 Tentang Wilayah Negara

16 Penjelasan Undang-Undang Nomor 43 Tahun 2008 Tentang Wilayah Negara
} 
wilayah, penegakan hukum dan kesejahteraan rakyat.

Keikutsertaan masyarakat dalam menjaga dan mempertahankan Wilayah Negara termasuk Kawasan Perbatasan.

Larangan dan sanksi bagi setiap orang yang melakukan pelanggaran terkait dengan Wilayah Negara dan batas-batasnya. Menyikapi bahwa pengelolaan terhadap kawasan perbatasan sangat diperlukan. Steven B.Jones dalam teorinya "Boundary Making Theory" membagi ruang lingkup pengelolaan perbatasan dalam empat bagian, yaitu: allocation, delimitation, demarcation dan administration/management. Keempat ruang lingkup pengelolaan perbatasan tersebut saling terkait satu dengan lainnya yang menandakan bahwa keempatnya merupakan satu rangkaian pengambilan keputusan yang saling berkait dalam pelaksanaannya. ${ }^{17}$

Tujuan pengelolaan batas wilayah negara dan kawasan perbatasan adalah menjadikan kawasan perbatasan sebagai wilayah yang berdaya saing, maju, makmur, mandiri, dan sejahtera, dengan mengandalkan kemampuan dan kekuatan sendiri dalam rangka menjamin keutuhan wilayah dan kedaulatan NKRI. ${ }^{18}$ Konsep dasar yang digunakan dalam pengembangan kawasan perbatasan yan dituiukkan sekaligus sebagai kawasan pengembangan aktivitas ekonomi dan perdagangan mengacu pada tiga pendekatan yang digunakan yaitu : pendekatan kesejahteraan pendekatan keamanan, dan pendekatan lingkungan. ${ }^{19}$

1. Konsep Kesejahteraan
2. Konsep Keamanan

3. Konsep Lingkungan

Pasal 14 Undang-Undang Nomor 43 Tahun 2008 menyatakan bahwa "Untuk mengelola Batas Wilayah Negara dan mengelola Kawasan Perbatasan pada tingkat pusat dan daerah,

Pemerintah dan pemerintah daerah membentuk Badan Pengelola Nasional dan Badan Pengelola Daerah."20 nilah yang menjadi dasar terbentuknya sebuah lembaga pengelola perbatasan yaitu Badan Nasional Pengelola Perbatasan (BNPP) dan Badan Nasional Pengelola Perbatasan di Daerah (BPPD). Terlihat jelas bahwa pengelolaan perbatasan bukan hanya tanggungjawab pemerintah pusat tetapi juga pemerintah daerah, dalam hal ini daerah yang memiliki kawasan perbatasan.

\subsection{Kewenangan Pemerintah Daerah}

Guna memperlancar pelaksanaan pemerintahan daerah maka asas-asas yang digunakan, yaitu asas desentralisasi, dekonsentrasi, dan tugas pembatuan (medebewind). Desentralisasi adalah penyerahan kewenangan dari pemerintah pusat kepada pemerintah daerah untuk mengurusi urusan rumah tangga sendiri berdasarkan prakarsa dan aspirasi dari rakyatnya dalam kerangka negara kesatuan Republik Indonesia. Dengan adanya desentralisasi maka memunculkan otonomi bagi suatu pemerintah daerah. Desentralisasi sebenarnya adalah istilah dalam keorganisasian yang secara sederhana didefinisikan sebagai penyerahan kewenangan. ${ }^{21}$ Secara konstitusional pemberian kewenangan otonomi daerah berdasarkan pada -

17 Budi Hermawan B.(2016). Loc.Cit. hlm. 55.

18 Badan Nasional Pengelola Perbatasan, Rencana Induk Pengelolaan Batas Wilayah Negara dan Kawasan Perbatasan Tahun 20112014. hlm. 160.

19 Ikhwanudin Mawardi. (2010). Strategi Pengembangan Pusat Kegiatan Strategis Nasional Di Kawasan Perbatasan Darat Sebagai Pintu Gerbang Aktivitas Ekonomi Dan Perdagangan Dengan Negara Tetangga. hlm. 4-7.

20 Pasal 14 Undang-Undang Nomor 43 Tahun 2008 Tentang Wilayah Negara

21 Syamsuddin Haris. (2007). Desentralisasi dan otonomi daerah. Jakarta: LIPPI Pres. hlm. 52. 
Pasal 18 Undang-Undang Dasar 1945.

Otonomi daerah merupakan konsekuensi dari desentralisasi teritorial. Wujudnya berupa hak, wewenang dan kewajiban daerah untuk mengatur dan mengurus rumah tangganya sendiri. 22 Desentralisasi dapat dibagi menjadi empat jenis :23

Desentralisasi Politik (political decentralization), yaitu pemberian hak kepada warga negara melalui perwakilan yang dipilih suatu kekuasaan yang kuat untuk mengambil keputusan publik.

Desentralisasi Administratif (administrative decentralization), yaitu pelimpahan kewenangan yang dimaksud untuk mendistribusikan kewenangan, tanggungjawab dan sumber-sumber keuangan untuk menyediakan pelayanan publik. Desentralisasi administratif pada dasarnya dapat dikelompokkan menjadi 3 (tiga) bentuk, yaitu :

Dekonsentrasi (deconcentration), yaitu pelimpahan wewenang dari pemerintah pusat kepada pejabat yang berada dalam garis hirarki dengan pemerintahan pusat di daerah.

Pendelegasian (delegation), yaitu pelimpahan wewenang untuk tugas tertentu kepada organisasi yang berada di luar struktur birokrasi reguler yang dikontrol secara tidak langsung oleh pemerintah pusat. Pendelegasian wewenang ini biasanya diatur dengan ketentuan perundangan. Pihak yang menerima wewenang mempunyai keleluasaan (discretion) dalam penyelenggaraan pendelegasian tersebut, walaupun wewenang terakhir tetap pada pihak pemberi wewenang (sovereign-authority).
Devolusi (devolution), yaitu pelimpahan wewenang kepada tingkat pemerintahan yang lebih rendah dalam bidang keuangan atau tugas pemerintahan dan pihak pemerintah daerah mendapat discreation yang tidak dikontrol oleh pemerintah pusat.

Desentralisasi Fiskal (fiscal decentralization), merupakan komponen utama dari desentralisasi. Apabila pemerintah daerah melaksanakan fungsinya secara efektif, maka mereka harus didukung sumber-sumber keungan yang memadai baik yang berasal dari pendapatan asli daerah, bagi hasil pajak dan bukan pajak, pinjaman maupun subsidi atau bantuan dari pemerintah pusat.

\section{Desentralisasi Ekonomi (economic or} market decentralization), intinya berkaitan dengan kebijakan pelimpahan fungsi-fungsi pelayanan kepada masyarakat dari pemerintah kepada sektor swasta sejalan dengan kebijakan liberalisasi dan ekonomi pasar.

Sebagai konsekuensi dari sistem pemerintahan daerah maka Pemerintah Daerah, khususnya Pemerintah Daerah Provinsi yang memiliki kawasan perbatasan memiliki tanggungjawab terhadap pengelolaan kawasan tersebut. Kewenangan Daerah Provinsi terhadap kawasan perbatasan berada pada Badan Pengelola Perbatasan di Daerah yang dibentuk melalui Peraturan Daerah. Peraturan daerah (Perda) merupakan instrumen dalam pelaksanaan otonomi daerah untuk menentukan arah dan kebijakan pembangunan daerah serta fasilitas pendukungnya. ${ }^{24}$

22 Irman dan Oksep Adhayanto. (2016). Perlindungan Hukum Terhadap Wilayah Perbatasan di Provinsi Kepulauan Riau. Prosiding Seminar Bersama Program Studi llmu Hukum Fisip Umrah Dengan Fakultas Hukum Universitas Islam Riau. hlm. 152

23 Ibid. hlm. 152-154

24 Muhammad Suharjo. (2014). Pembentukan Peraturan Daerah Yang Responsif Dalam Mendukung Otonomi Daerah.Jurnal IImu Hukum. 10 (19). hlm. 22. 
Khususnya untuk Provinsi Kepuluan Riau telah mengalami beberapa perubahan atau alih fungsi terhadap kewenangan pengelolaan perbatasan di daerah. Dinamika dalam kelembagaan ini merupakan bagian dari politik hukum pemerintah dalam mengelola kawasan perbatasan dimana Politik hukum menurut Imam Syaukani adalah kebijakan dasar penyelenggara negara dalam bidang hukum yang akan, telah dan sedang berlaku, yang bersumber dari nilai-nilayang berlaku didalam masyarakat untuk mencapai tujuan negara yang dicita-citakan. ${ }^{25}$ Politik Hukum menganut prinsip double movement, yaitu selain sebagai kerangka fikir merumuskan kebijakan dalam bidang hukum (legal policy) oleh lembaga-lembaga negara yang berwenang, ia juga dipakai untuk mengkritisi produkproduk hukum yang telah diundangkan. Berdasarkan hal tersebut, maka terdapat beberapa ruang lingkup atau wilayah kajian politik hukum sebagai berikut: ${ }^{26}$

Proses pengalian nilai-nilai dan aspirasi yang berkembang dalam masyarakat oleh penyelenggara negara yang berwenang merumuskan politik hukum;

Proses perdebatan dan perumusan nilai-nilai dan aspirasi tersebut ke dalam bentuk sebuah rancangan peraturan perundang-undangan oleh penyelenggara negara yang berwenang merumuskan politik hukum;

1. Penyelenggara negara yang berwenang merumuskan dan menetapkan politik hukum;

2. Peraturan perundang-undangan yang memuat politik hukum;
3. Faktor-faktor yang mempengaruhi dan menentukan suatu politik hukum, baik yang akan, sedang, dan telah ditetapkan;

4. Pelaksanaan dari peraturaan perundangundangan yang merupakan implementasi dari politik hukum suatu negara.

Syaukani dalam bukunya yang berjudul dasar-dasar politik hukum menginterpretasikan makna politik hukum yang disampaikan oleh Garuda nusantara menjadi beberapa konsep diantaranya: ${ }^{27}$ Pelaksanaan ketentuan hukum yang telah ada secara konsiten. Pembangunan hukum yang intinya adalah pembaharuan terhadap ketentuan hukum yang telah ada dan dianggap usang, dan penciptaan ketentuan hukum yang diperlukan untuk memenuhi tuntutan perkem-bangan yang terjadi dalam masyarakat.

Penegasan fungsi lembaga penegak atau pelaksana hukum dan pembinaan anggotanya.

Meningkatkan kesadaran hukum masyarakat menurut persepsi kelompok elit pengambilan kebijakan.

Apabila melihat konsep politik hukum diatas dapat dikatakan bahwa politik hukum pengelolaan kawasan perbatasan didaerah memerlukan konsistensi dalam pengelolaan kawasan perbatasan. Apabila memerlukan pembaharuan maka pembaharuan tersebut seharusnya dapat menjawab kendala-kendala serta hambatan-hambatan yang ada. Sehingga tujuan dari politik hukum tersebut dapat tercapai.

25 Muhammad Suharjo. (2014). Pembentukan Peraturan Daerah Yang Responsif Dalam Mendukung Otonomi Daerah.Jurnal IImu Hukum. 10 (19). hlm. 22.

26 Iman Syaukani, Op.Cit. hllm. 22.

27 Ibid, hlm. 152-154. 


\section{Pembahasan}

\subsection{Politik Hukum Pengelolaan Kawasan Perbatasan (Studi Kasus Badan Pengelola Perbataasan Provinsi Kepulauan Riau)}

Politik hukum merupakan alat yang digunakan pemerintah dalam mencapai tujuan negara yaitu kesejahteraan. Politik hukum menurut Menurut Imam Syaukani dan A.Thohsin Thohari dalam perspektif akademis tidak hanya berbicara sebatas pengertian tetapi mengkritisi juga produk-produk hukum yang telah terbentuk. Dengan demikian, Politik hukum menganut prinsip double movement, yaitu selain sebagai kerangka fikir merumuskan kebijakan dalam bidang hukum (legal policy) oleh lembaga-lembaga negara yang berwenang, juga dipakai untuk mengkritisi produk- produk hukum yang telag diundangkan berdasarkan legal policy. Sebagai negara hukum salah satu syaratnya adalah pemerintahan yang dijalankan berdasarkan hukum, oleh karena itu konsekuensinya adalah segala bidang didalam penyelenggaraan negara memerlukan politik hukum termasuk dalam bidang pengelolaan kawasan perbatasan.

Penulis akan menguraikan pembahasan terkait dinamika kelembagaan ini dalam beberapa bagian yaitu latar belakang dibentuknya BPPD, Peran BPPB, Biro Pemerintahan dan Perbatasan sebagai pengganti BPPD, dan Pembentukan Kembali BPPD berdasarkan Peraturan Menteri Dalam Negeri Nomor 140 Tahun 2014 Tentang Pembentukan Badan Pengelola Perbatasan di Daerah.

Latar Belakang dibentuknya BPPD. Pengelolaan kawasan perbatasan di Negara Indonesia berlandas pada konstitusi pasal $25 \mathrm{~A}$.
Mengingat kawasan perbatasan merupakan kawasan strategis dalam menjaga integritas Wilayah Negara, Undang-Undang 43 Tahun 2008 Tentang Wilayah Negara hadir sebagai peraturan yang membahas terkait kawasan pengelolaan kawasan perbatasan. Berdasarkan pada amanat Undangundang tersebut saat ini kawasan perbatasan dikelola oleh suatu lembaga negara yaitu Badan Nasional Pengelola Perbatasan (BNPP) yang bertanggungjawab langsung kepada presiden.

Hadirnya BNPP pada tahun 2010 merupakan langkah awal pemerintah agar pengeloaan perbatasan lebih terintegrasi dan sesuai dengan konsep kesejahteraan, keamanan, serta lingkungan. Tugas BNPP berdasarkan Pasal3 Peraturan Presiden Nomor 12 Tahun 2010 Tentang Badan Nasional Pengelola Perbatasan adalah menetapkan kebijakan program pembangunan perbatasan, menetapkan rencana kebutuhan anggaran, mengoordinasikan pelaksanaan, dan melaksanakan evaluasi dan pengawasan terhadap pengelolaan Batas Wilayah Negara dan Kawasan Perbatasan. BNPP dalam menjalankan tugas dan kewenangannya didaerah dibantu oleh Badan Pengelola Perbatasan Daerah (BPPD). BPPD dibentuk di Provinsi dan Kabupaten/Kota yang memiliki kawasan perbatasan. Salah satu Provisi yang memiliki BPPD adalah Provinsi Kepulauan Riau.Provinsi Kepulauan Riau memiliki batas wilayah:

Sebelah Utara dengan Laut Cina Selatan;

Sebelah Timur dengan Negara Malaysia dan Provinsi Kalimantan Barat;

Sebelah Selatan dengan Provinsi Sumatera

Selatan dan Provinsi Jambi; dan; 
Sebelah Barat dengan negara Singapura, Malaysia, dan Provinsi Riau.

Kawasan Perbatasan Provinsi kepulauan yang cukup banyak ternyata sebanding dengan banyaknya isu dan permasalahan perbatasan yang harus dihadapi oleh Provinsi Kepulauan Riau yang sebelumnya sudah penulis paparkan didalam latar belakang. Berdasarkan letak geografis Provinsi Kepulauan Riau yang dapat dikatakan sebagai miniatur dari Negara Indonesia setra beragam isu dan permasalahan perbatasan di Provinsi Kepulauan Riau sangat memerlukan penanganan yang optimal.

Dilihat dari aspek yuridis pembentukan BPP Provinsi Kepulauan Riau berdasar pada konsep otonomi daerah serta amanat Undang-Undang 43 Tahun 2008 bahwa dalam menjalankan tugas didaerah BNPP dibantu olek BPPD. Lanjutannya adalah Peraturan Menteri Dalam Negeri Nomor 2 Tahun 2011 Tentang Pedoman Pembentukan Badan Pengelola Perbatasan Di Daerah dan dilanjutkan dengan Peraturan Daerah Nomor 5 Tahun 2011 tentang Organisasi Dan Tata Kerja Inspektorat, Badan Perencanaan Pembangunan Daerah, Lembaga Teknis Daerah, Satuan Polisi Pamong Praja Dan Lembaga Lain Provinsi Kepulauan Riau.

BPP Provinsi Kepulauan Riau dibentuk dengan visi "Terwujudnya kawasan perbatasan laut yang aman dan sejahtera sebagai beranda depan negara di provinsi kepulauan riau" seta Misi sebagai berikut :

1. Menguatkan koordinasi, integrasi, sinergi, dan sinkronisasi antar sektor dan antar daerah dalam pengelolaan perbatasan.
2. Melaksanakan fasilitasi, inventarisasi dan penyediaan sarana dan prasarana wilayah dikawasan-kawasan perbatasan.

3. Melakukan fasilitasi pengembangan ekonomian kawasan perbatasan yang berorientasi ke luar (outward looking) dan didukung pusat-pusat pertumbuhan dan sumber daya alam lokal.

BPP Provinsi Kepulauan Riau dibentuk dengan visi "Terwujudnya kawasan perbatasan laut yang aman dan sejahtera sebagai beranda depan negara di provinsi Kepulauan Riau" seta Misi sebagai berikut:

a. Menguatkan koordinasi, integrasi, sinergi, dan sinkronisasi antar sektor dan antar daerah dalam pengelolaan perbatasan.

b. Melaksanakan fasilitasi, inventari-sasi dan penyediaan sarana dan prasarana wilayah dikawasan-kawasan perbatasan.

c. Melakukan fasilitasi pengembangan ekonomian kawasan perbatasan yang berorientasi ke luar (outward looking) dan didukung pusat-pusat pertumbuhan dan sumber daya alam lokal.

d. Meningkatkan pengawasan pembangunan dan penegakan hukum di kawasan perbatasan.

e. Meningkatkan keberdayaan dan semangat kebangsaan masyarakat dikawasan perbatasan. 
4. Berdasarkan visi dan misi terbentuknya BPP Provinsi Kepulauan Riau diharapkan menjadi acuan serta motivasi BPP Provinsi Kepulauan Riau dalam pengelolan kawasan perbatasan. BPP sebagai perpanjangan tangan dari pemerintah pusat didaerah dalam pengelolaan perbatasan diharapkan mampu untuk menangani kompleknya permasalahan di kawasan perbatasan dengan tetap berkoordinasi dengan pemerintah pusat dan pemerintah daerah.

\subsection{Peran BPPD}

BPPD dipimpin oleh seorang Kepala Badan yang berada di bawah dan bertanggung jawab kepada Gubernur secara teknis administratif melalui Sekretaris Daerah. BPP Provinsi memiliki tugas menetapkan kebijakan program pembangunan perbatasan, menetapkan rencana kebutuhan anggaran, mengoordinasikan pelaksanaan, dan melaksanakan evaluasi dan pengawasan di provinsi. ${ }^{28}$ Sedangakan tugas BPP

Provinsi Kepulauan Riau berdasarkan peraturan daerah adalah merumuskan dan melaksanakan kebijakan teknis di bidang Pengelola Perbatasan serta melaksanakan tugas dekonsentrasi dan tugas pembantuan yang diserahkan oleh Gubernur sesuai dengan lingkup tugasnya. ${ }^{29}$

BPP Provinsi dalam menjalankan tugasnya memiliki fungsi sebagai berikut :

Tabel 4.1.

Fungsi Badan Pengelola Perbatasan Provinsi

Peratruran Menteri Dalam Negeri Nomor 2 Tahun 2011 Tentang Pedoman Pembentukan Badan Pengelola Perbatasan Di Daerah
Peraturan Daerah Nomor 5 Tahun 2011 tentang Organisasi Dan Tata Kerja Inspektorat, Badan Perencanaan Pembangunan Daerah, Lembaga Teknis Daerah, Satuan Polisi Pamong Praja Dan Lembaga Lain Provinsi Kepulauan Riau.

\section{Pasal 10}

(1) penyusunan dan penetapan rencana aksi pembangunan batas wilayah negara dan kawasan perbatasan di provinsi;

(2) pengoordinasian penetapan kebijakan dan pelaksanaan pembangunan, pengelolaan serta pemanfaatan batas wilayah negara dan kawasan perbatasan di provinsi;

(3) Pengelolaan dan fasilitasi penegasan, pemeliharaan dan pengamanan batas wilayah negara di provinsi;

(4) Inventarisasi potensi sumber daya dan rekomendasi penetapan zona pengembangan ekonomi, pertahanan, sosial budaya, lingkungan hidup dan zona lainnya di kawasan perbatasan provinsi;

(5) Penyusunan program dan kebijakan pembangunan sarana dan prasarana
Pasal 149

(1) Pelaksanaankegiatan kesekretariatan, meliputi pembinaan dan evaluasi, keuangan, umum dan kepegawaian;

(2) Pengelola Perbatasan Pemerintah Provinsi Kepulauan Riau;

(3) Pembinaan pelaksanaan Pengelola Perbatasan;

(4) Pengumpulan data dan bahan penyusunan pedoman dan petunjuk teknis Pengelola Perbatasan;

(5) Penyiapan data dan bahan pembinaan dan petunjuk teknis penyelenggaraan Pengelola Perbatasan, potensi kawasan dan infrastruktur kawasan;

(6) Pelaksanaan evaluasi Pengelola Perbatasan Provinsi Kepulauan

28 Pasal 8 Peratruran Menteri Dalam Negeri Nomor 2 Tahun 2011 Tentang Pedoman Pembentukan Badan Pengelola Perbatasan Di Daerah

29 Pasal 148 Peraturan Daerah Nomor 5 Tahun 2011 tentang Organisasi Dan Tata Kerja Inspektorat, Badan Perencanaan Pembangunan Daerah, Lembaga Teknis Daerah, Satuan Polisi Pamong Praja Dan Lembaga Lain Provinsi Kepulauan Riau 


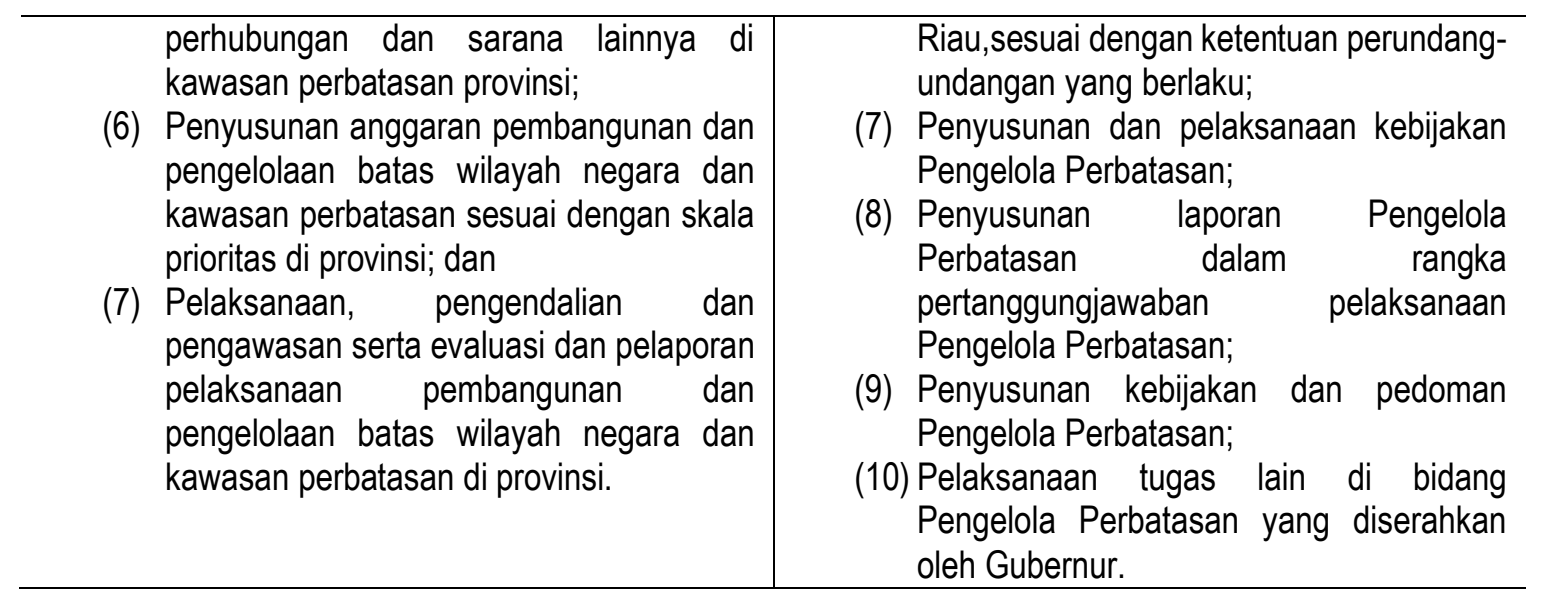

Berdasarkan tugas dan fungsi tersebut terlihat bahwa ada perbedaan antara tugas BPPD yang tercantum didalam Peraturan menteri dengan tugas yang tercantum didalam peraturan daerah Provinsi Kepuluauan Riau, sama halnya juga dengan fungsi. Menurut penulis bahwa tugas yang tercantum didalam peraturan daerah terlihat lebih sempit dan sifatnya lebih umum dibandingkan dengan yang tercantum didalam peraturan menteri. Buktinya adalah didalam peraturan menteri jelas bahwa tugas BPPD berada pada tataran penetapan kebijakan, penetapan anggaran, koordinasi serta pengawasan. Bukti bahwa tugas BPPD didalam perda terlihat dipersempit dan lebih umum yaitu hanya merumuskan dan melaksanakan kebijakan teknis serta melaksanakan tugas dekonsentrasi dan tugas pembantuan. Terkait fungsi telah penulis bandingan melalui tabel diatas.

Terlihat sama halnya dengan tugas, bahwa fungsi yang ada didalam peraturan daerah lebih sempit dan sifatnya lebih umum. Hal ini tentu tidak sesuai dengan teori terkait muatan didalam peraturan perundang-undangan. Berdasarkan hirarki peraturan perundang-undangan bahwa perda lebih rendah hirarkinya dibanding peraturan menteri. Materi muatan peraturan daerah merupakan penjabaran lebih lanjut dari peraturan diatasnya bukan malah sebaliknya.

Tugas dan fungsi dari BPPD akan penulis kaitkan dengan data program, strategi serta capaian kinerja BPP Provinsi Kepulauan Riau selama beroprasi, karena program, strategi serta capaian kinerja merupakan bentuk implementasi dari tupoksi. Berdasarkan data yang peneliti temukan saat penelian bahwa selama BPP Provinsi Kepulauan Riau beroprasi memiliki beberapa program diantaranya adalah Pelayanan Administrasi Perkantoran, Peningkatan Pengembangan Sistem Pelaporan Capaian Kinerja dan Keuangan, Peningkatan Sarana dan Prasarana Aparatur, Pengembangan Wilayah Perbatasan, Perencanaan Pembangunan Daerah.

Bentuk implementasi yang lebih kongkret akan terlihat dari capaian kinerja. Capaian kinerja BPP Provinsi kepri dalam kurun waktu tahun 20122015 ditunjukkan dengan capaian indikator data potensi pulau-pulau terdepan di Provinsi Kepulauan Riau, Data Pengelolaan Kawasan Perbatasan di Provinsi Kepulauan Riau, dan Dokumen Risalah Persidangan. Capaian indikator lainnya yaitu jumlah 
media informasi/publikasi kawasan perbatasan ratarata sejumlah 4 kali Majalah terbit dan 1 kali pameran potensi, dan jumlah masyarakat di wilayah perbatasan memiliki pemahaman batas negara dan rasa nasionalisme melalui pelaksanaan workshop, peningkatan peran serta nelayan dalam menjaga batas wilayah negara, Sosialisasi Pengelolaan Batas Negara, Seminar Perbatasan, dan Penguatan Kelembagaan di kawasan perbatasan. ${ }^{30}$

Berdasarkan uraian tersebut capaian kinerja umumnya berupa pendataan. Perlu ada peningkatan kinerja dalam pengelolaan kawasan perbatasan, baik dalam pengembangan ekonomi masyarakat, pengkoordinasian pembangunan infrastruktur pada 19 (sembilan belas) lokasi prioritas, serta peningkatan kualitas pelayanan publik. Sejatinya pengelolaan perbatasan harus sesuai dengan tugas dan fungsi sehingga pengelolaan kawasan perbatasan dapat dirasakan secara optimal.

Jumlah lokpri yang tidak sedikit tersebut tentunya membutuhkan kerja keras serta komitmen agar seluruh Lokpri dapat tertangani. Pada kenyataannya banyaknya Lokpri tersebut ternyata sebanding dengan banyaknya isu dan permasalahan di kawasan perbatasan Provinsi Kepulauan Riau. Sampai dengan pada tahun 2015, BPPD dalam menjalankan tugas dan fungsinya memiliki beberapa kendala antara lain :

1. Persepsi tentang pembangunan perbatasan masih berbeda.

2. Penanganan masih parsial, bersifat sektoral dan belum terintegritasi.

3. Koordinasi belum berjalan dengan baik, baik antara sektoral, tingkat pusat maupun antar pemerintah pusat dengan pemerintah daerah.

4. Komitmen Anggaran pembangunan perbatasan di daerah relatif masih minim. Kendala yang dihadapi BPP Provinsi Kepulauan Riau dapat secara umum dikarenakan pengelolaan kawasan perbatasan yang belum terintegrasi keseluruhannya. Pelaksanaan pembangunan secara fisik masih tersebar pada beberapa perangkat daerah. Terutama terkait pembangunan infrastuktur berada para Dinas Pekerjaan Umum. Sehingga mengakibatkan sulitnya koordinasi karena antar sector masih memiliki ego masing-masing dalam pengelolaan perbatasan. Kendala juga berada pada anggaran, 41 Lokpri dengan akses yang belum memadai di Provinsi Kepulauan Riau memerlukan anggaran yang cukup besar namun berdasarkan data yang diperoleh anggaran yang tersedia belum dapat mencukupi untuk mengatasi secara optimal permasalahan perbatasan di Provinsi Kepulauan Riau.

Menurut penulis, kendala yang dihadapi oleh BPP Provinsi Kepulauan Riau terkait seharusnya dapat diatasi dengan memanfaatkan kewenagan, tugas dan fungsi dimiliki oleh Badan Pengelola Perbatasan secara optimal. Sesuai dengan Peraturan Menteri Dalam Negeri terkait BPPD, Kewenangan dan tupoksi yang dimiliki oleh BPPD berada pada tataran penyusunan dan penetapan kebijakan dan anggaran, inventarisasi, koordinasi serta pengawasan. Penulis memandang bahwa berdasarkan peraturan terkait kewenangan serta tupoksi BPPD telah memadai.

Peraturan Menteri terkait telah mengakomodir kewenangan dan tupoksi yang mem-

30 RPJMD Provinsi Kepulauan Riau Tahun 2016-2021, bagian II, hlm. 117 
52 Okky Razma \& Pery RS, Politik Hukum Pengelolaan Kawasan Perbatasan...

adai hanya saja lanjutan dari peraturan tersebut dalam hal ini perda mempersempit serta membuatnya menjadi terlihat lebih umum sehingga berimbas kepada program dan capaian kinerja yang juga menjadi tidak optimal. Seharusnya pemerintah dapat lebih jeli dalam menyusun serta mengimplementasikan politik hukum dalam pengelolaan kawasan perbatasan. Terkecuali masalah anggaran, anggaran dalam pengelolaan perbatasan memanglah masih minim dan perlu ada peningkatan anggaran yang dialokasikan untuk pengelolaan perbatasan.

Biro Penerintahan dan Perbatasan sebagai pengganti BPP Provinsi Kepulauan Riau. Ketika BPP

Provinsi Kepulauan Riau sedang berusaha terus berjalan dengan kendala dan hambatan yang ada, terjadi perubahan pada politik hukum pemerintah, Undang-Undang Nomor 32 Tahun 2004 Tentang Pemerintah Daerah diubah menjadi Undang-Undang Nomor 23 Tahun 2014 yang salah satu implikasinya bagi Provinsi Kepulauan Riau adalah beralihnya kewenangan pengeloaan kawasan perbatasan dari BPPD kepada perangkat daerah baru yaitu Biro Pemerintahan dan Perbatasan.

Latar belakang hadirnya biro ini adalah dari Undang-Undang Pemerintahan Daerah yang baru dan Peraturan Pemerintah Nomor 18 Tahun 2016, disitu tidak ada urusan yang diakomodir oleh BPPD oleh karena itu hadir Perda Kepri Nomor 7 Tahun 2016 dan Pergub Nomor 60 Tahun 2016 disitu tidak ada urusan yang diakomodir oleh BPPD oleh karena itu hadir Perda Kepri Nomor 7 Tahun 2016 dan Pergub Nomor 60 Tahun 2016 bahwa didalam ketentuan ini tidak disebutkan terkait BPPD maka secara structural pengelolaan perbatasan diakomodir oleh bagian perbatasan di Biro Pemerintahan dan Perbatasan." 31

Secara filosofis Pasal 231 Undang-Undang Pemerintahan Derah adalah ingin mengefektifkan kelembagaan didaerah. Peralihan fungsi dari BPPD kepada Biro Pemerintahan dan Perbatasan adalah bahwa pengelolaan perbatasan sampai saat ini masih tersebar pada beberapa instansi, BPPD hanya sebagai koordinator oleh karena itu pasal 231 Undang-Undang Pemerintahan Daerah berimplikasi pada BPPD. Hal ini adalah bentuk efektifitas dari kelembagaan didaerah.

"Untuk mengelola kawasan perbatasan kami di biro pemerintahan dan perbatasan khususnya pada bagian perbatasan hanya terdiri dari 5 orang yang sebelumnya pada saat di BPPD ada 10 orang"32

Dari pernyataan diatas terlihat bahwa dalam pengelolaan kawasan perbatasan dengan beban Kepulauan Riau yang memiliki 22 (dua puluh dua) pulau terluar dengan 41 Lokpri serta dengan isu dan permasalahan perbatasan yang cukup banyak dapat dikatakan kekurangan kuantitas sumberdaya manusia. Biro Pemerintahan dan Perbatasan terbagi menjadi tiga bagian yaitu Bagian Pemerintahan, Bagian Perbatasan dan Bagian Otonomi Daerah. Bagian yang fokus terhadap perbatasan hanya di bidang perbatasan. Bidang perbatasan hanya terdiri dari 5 orang yang dipimpin oleh kepala bagian dengan pangkat eselon II.

Biro Pemerintahan dan Perbatasan pada bagian pengelolaan perbatasan mempunyai tugas melakukan penyusunan, perumusan rencana induk dan rencana aksi serta pengoordinasian penyusunan kebijakan dan pengelolaan serta pemanfaatan per-

31 Hasil wawancara langsung kepada Bapak Wasrizal selaku Kepala bagian perbatasan negara Biro Pemerintahan dan Perbatasan Provinsi Kepulauan Riau, pada Hari Selasa 10 Juli 2018, pukul 11.00 WIB.

32 Hasil wawancara langsung kepada Bapak Wasrizal selaku Kepala bagian perbatasan negara Biro Pemerintahan dan Perbatasan Provinsi Kepulauan Riau, pada Hari Selasa 10 Juli 2018, pukul 11.10 WIB. 
batasan antar negara, perbatasan antar daerah dan urusan tata usaha. ${ }^{33}$ Terkait fungsi biro pemerintahan dan perbatasan pada bagian perbatasan akan penulis bandingkan dengan fungsi pada BPPD yaitu sebagai berikut :

Tabel 4.2

Perbandingan Fungsi BPPD dan Biro

\begin{tabular}{|c|c|}
\hline $\begin{array}{l}\text { Peraturan Daerah Nomor } 5 \text { Tahun } 2011 \text { tentang } \\
\text { Organisasi Dan Tata Kerja Inspektorat, Badan } \\
\text { Perencanaan Pembangunan Daerah, Lembaga } \\
\text { Teknis Daerah, Satuan Polisi Pamong Praja Dan } \\
\text { Lembaga Lain Provinsi Kepulauan Riau. }\end{array}$ & $\begin{array}{l}\text { Peraturan Peraturan Gubernur Kepulauan Riau } \\
\text { Nomor } 60 \text { Tahun } 2016 \text { Tentang Kedudukan, } \\
\text { Susunan Organisasi, Tugas Dan Fungsi, Serta Tata } \\
\text { Kerja Perangkat Daerah }\end{array}$ \\
\hline 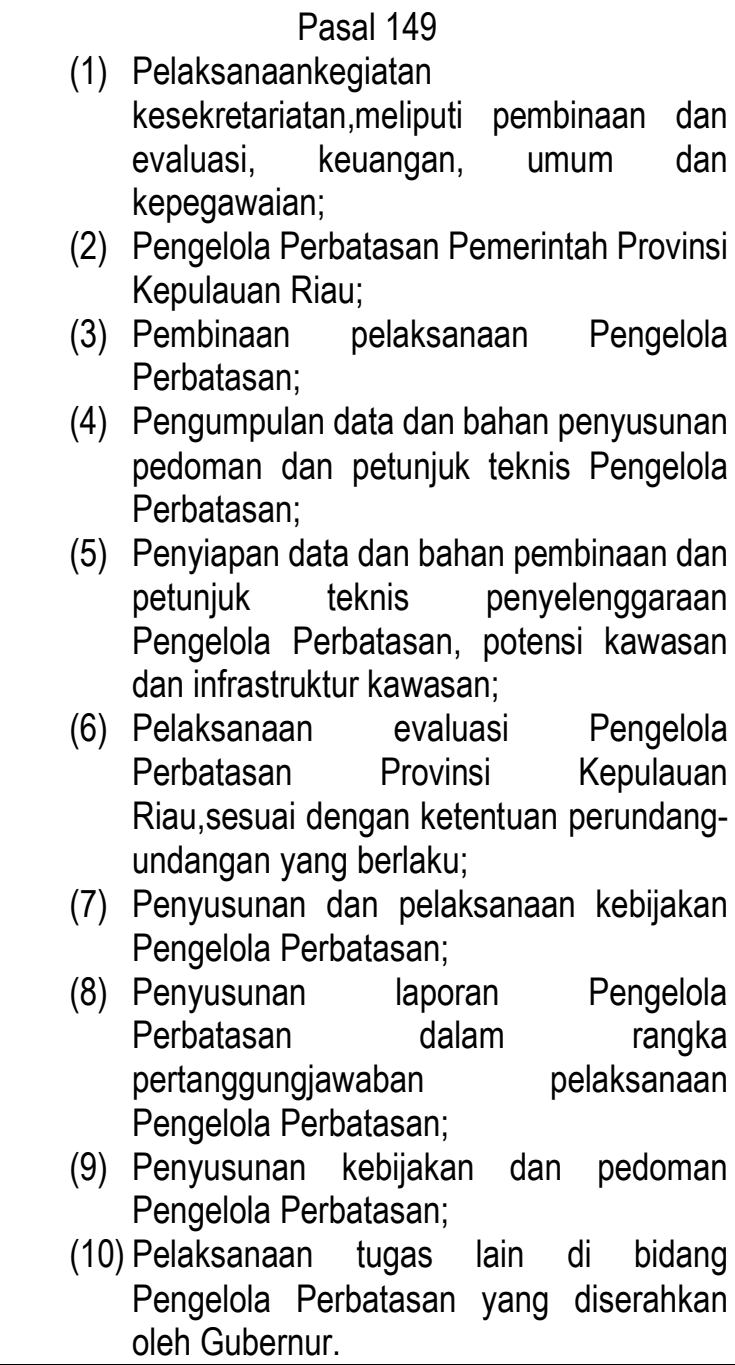 & $\begin{array}{l}\text { Pasal } 16 \text { ayat (2) } \\
\text { (1) Pengumpulan data bahan penyusunan } \\
\text { pedoman dan petunjuk teknis pengelola } \\
\text { perbatasan; } \\
\text { (2) Penyiapan data dan bahan pembinaan dan } \\
\text { petunjuk teknis penyelenggaraan } \\
\text { pengelola perbatasan, potensi kawasan } \\
\text { dan infrastuktur kawasan; } \\
\text { (3) Pelaksanaan evaluasi pengelola } \\
\text { perbatasan provinsi kepulauan riau sesuai } \\
\text { dengan ketentuan perundang-undangan; } \\
\text { (4) Penyusunan dan pelaksanaan kebijakan } \\
\text { pengelola perbatasan; } \\
\text { (5) Penyusunan laporan pengelola perbatasan } \\
\text { dalam rangka pertanggungjawaban } \\
\text { pelaksanaan pengelola perbatasan; dan } \\
\text { (6) Pelaksanaan tugas kedinasan lain yang } \\
\text { diberikan oleh kepala biro. } \\
\text { (7) }\end{array}$ \\
\hline
\end{tabular}

Berdasarkan uraian tugas dan fungsi dari bagian perbatasan pada Biro Pemerintahan dan Perbatasan terlihat bahwa kewenangannya masih berada pada tataran koordinasi dan tidak dapat melaksanakan pembangunan secara fisik. Pembangunan terhadap pengelolaan perbatasan masih tetap tersebar pada OPD teknis. Biro Pemerintahan dan Perbatasan hanya sebatas koordinasi sedangkan sesuai dengan

33 Hasil wawancara langsung kepada Bapak Wasrizal selaku Kepala bagian perbatasan negara Biro Pemerintahan dan Perbatasan Provinsi Kepulauan Riau, pada Hari Selasa 10 Juli 2018, pukul 11.00 WIB. 
Undang-Undang Pemerintah Daerah bahwa unsur pelaksana kebijakan didaerah adalah dinas terkait. Biro melakukan koordinasi terkait pengelolaan perbatasan dengan BNPP maupun dengan Pemerintah Daerah dalam hal ini perangkatperangkat daerah terkait yang secara teknis menangani pengelolaan kawasan perbatasan.

Berdasarkan tabel diatas terlihat perbandingan fungsi antara BPPD dengan bagian perbatasan pada Biro Pemerintahan dan Perbatasan. Secara umum fungsi pada BPPD dan Biro adalah sama yaitu terkait pendataan-pendataan serta penyusunan program dan evaluasi. Tugas dan fungsi yang secara umum sama namun dengan beban kerja yang lebih berat membuat pengelolaan kawasan perbatasan menjadi semakin tidak optimal.

Kegiatan yang telah dilakukan oleh biro pemerintahan dan perbatasan selama tahun 2017 dan 2018 adalah sebagai berikut:

1) Tahun 2017 Rapat Koordinasi Pembangunan Kawasan Perbatasan

(Seluruh Camat Lokasi Prioritas Kepulauan Riau) Sosialisai Kawasan Perbatasan (Desa berakit, Kecamatan Belakang Padang)

2) Tahun 2018 Kajian Pemetaan dan Kawasan Perbatasan Monitoring Evaluasi Pembangunan Kawasan Perbatasan

Kegiatan yang dilakukan Biro Pemerintahan dan Perbatasan yang terlihat pada table diatas merupakan bukti bahwa Biro hanya bekerja pada tataran koordinasi. Usulan terhadap pembangunan kawasan perbatasan akan disampaikan kepada Biro setelah itu Biro yang akan menyampaikannya ke Pemerintah Pusat.
"Anggaran untuk beberapa kegiatan bisa dikatakan minim karena kami tidak dapat tunjangan dari dana dekonsentrasi, kemarin sempat ada dana dekonsentrasi sekita 500 juta untuk pengelolaan perbatasan namun tidak bisa sampai ke Biro karena dana dekon hanya bisa diturunkan ketika ada lembaga berbentuk Badan seperti dulu, oleh karena itu dana tersebut ditarik lagi oleh pusat." ${ }^{34}$

Minimnya Anggaran merupakan salah satu hambatan dalam pengelolaan kawasan perbatasan. Sebelumnya pada saat pengelolaan kawasan perbatasan berada pada BPPD, terdapat anggaran dari dana dekonsentrasi Setelah beralih fungsi kepada Biro dengan porsi permasalahan yang sama bahkan bertambah dengan bertambahnya identifikasi terkait pulau terluar yang sebelumnya 19 (Sembilan belas) menjadi 22 (dua puluh dua) pulau justru pada kenyataannya anggaran semakin minim yang dibuktikan dengan tidak adanya lagi dana dekonsentrasi.

Dana dekonsentrasi merupakan dana pelimpahan wewenang dari pemerintah pusat kepada gubernur atau instansi vertikal dari pusat untuk mendukung pelaksanaan kegiatan dekonsentrasi. BPPD pada saat itu melaksanakan kegiatan didaerah berdasarkan dekonsentrasi dan tugas pembantuan. Dana dekonsentrasi bisa diberikan ketika didalam daerah tersebut pengelolaan perbatasan berapa pada tingkat Badan.

Penulis menyimpulkan dalam hal ini Peralihan dari BPPD kepada Biro Pemerintahan dan Perbatasan dalam hal pengelolaan perbata asan merupakan langkah yang kurang tepat. Ruang lingkup Biro lebih kecil dari pada lembaga negara setingkat Badan dibuktikan dengan minimnya kuantitas SDM serta anggaran pada biro membuat

34 Hasil wawancara langsung kepada Bapak Wasrizal selaku Kepala bagian perbatasan negara Biro Pemerintahan dan Perbatasan Provinsi Kepulauan Riau, pada Hari Selasa 10 Juli 2018, pukul 11.00 WIB. 
pengelolaan perbatasan semakin terasa sulit tertangani. Terlebih lagi dapat dilihat bahwa pekerjaannya yang harus ditangani lebih berat (Identifikasi pulau terdepan dari 19 pulau menjadi 22 pulau). Hal ini mengakibatkan pengelolaan perbatasan yang tidak optimal.

Pembentukan Kembali BPPD berdasarkan Peraturan Menteri Dalam Negeri Nomor 140 Tahun 2017 Tentang Pembentukan Badan Pengelola
Perbatasan di Daerah Semangat pembangunan kawasan perbatasan yang ingin dijadikan beranda terdepan negara ternyata hidup kembali dengan hadirnya Peraturan Menteri Dalam Negeri Nomor 140 Tahun 2017 Tentang Pembentukan Badan Pengelola Perbatasan di Daerah. Berdasarkan penelitian yang penulis lakukan dari bentuk penelusuran peraturan perundang-undangan dapat disimpulkan tidak ada perubahan kewenangan.

Tabel 4.3.

Kewenangan Badan Pengelola Perbatasan Provinsi

\begin{tabular}{|c|c|}
\hline $\begin{array}{l}\text { Peraturan Menteri Dalam Negeri Nomor } 2 \text { Tahun } \\
2011 \text { Tentang Pedoman Pembentukan Badan } \\
\text { Pengelola Perbatasan Di Daerah }\end{array}$ & 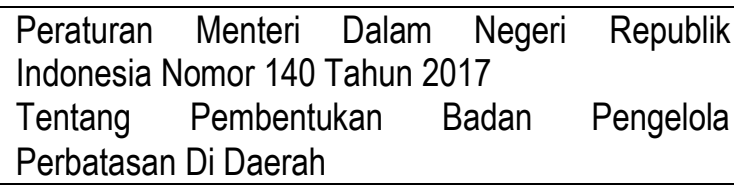 \\
\hline $\begin{array}{l}\text { Pasal } 6 \\
\text { (1) BPP Provinsi dalam pengelolaan wilayah } \\
\text { negara dan kawasan perbatasan } \\
\text { mempunyai wewenang: } \\
\text { (2) Melaksanakan kebijakan Pemerintah dan } \\
\text { menetapkan kebijakan lainnya dalam } \\
\text { rangka otonomi daerah dan tugas } \\
\text { pembantuan; } \\
\text { (3) Melakukan koordinasi pembangunan di } \\
\text { Kawasan Perbatasan; } \\
\text { (4) Melakukan pembangunan Kawasan } \\
\text { Perbatasan antar-pemerintah daerah } \\
\text { dan/atau antara pemerintah daerah } \\
\text { dengan pihak ketiga; dan } \\
\text { (5) Melakukan pengawasan pelaksanaan } \\
\text { pembangunan Kawasan Perbatasan yang } \\
\text { dilaksanakan } \\
\text { Kabupaten/Kota. }\end{array}$ & $\begin{array}{l}\text { Pasal } 8 \\
\text { (1) BPPD Provinsi dalam pengelolaan wilayah } \\
\text { negara dan kawasan perbatasan } \\
\text { mempunyai wewenang: } \\
\text { (2) Melaksanakan kebijakan Pemerintah dan } \\
\text { menetapkan kebijakan lainnya untuk } \\
\text { otonomi daerah dan tugas pembantuan; } \\
\text { (3) Melakukan koordinasi pembangunan di } \\
\text { Kawasan Perbatasan; } \\
\text { (4) Melakukan pembangunan Kawasan } \\
\text { Perbatasan antarpemerintah daerah } \\
\text { dan/atau antara pemerintah daerah } \\
\text { dengan pihak ketiga; dan } \\
\text { (5) Melakukan pengawasan pelaksanaan } \\
\text { pembangunan Kawasan Perbatasan yang } \\
\text { dilaksanakan Pemerintah daerah } \\
\text { Kabupaten/Kota. }\end{array}$ \\
\hline
\end{tabular}

Menurut hemat penulis, bahwa dapat dilihat dari table diatas kewenangan BPPD pada permendagri yang baru ternyata sama dan tidak ada perubahan kewenangan terhadap permendagri sebelumnya. Berdasarkan pembahasan sebelumya BPPD pada periode sebelumnya menyatakan bahwa perlu adanya penguatan kewenangan BPPD yang hanya berada pada tataran koordinasi mengalami kendala dan hambatan serta memerlukan penguatan kewengan sehingga pengelolaan kawasan perbatasan dapat berjalan secara optimal. Namun sebenarnya yang diperlukan adalah meningkatkan koordinasi. 
BPPD Provinsi berdasarkan Peraturan Menteri

Dalam Negeri Nomor 140 Tahun 2017 Tentang

Pembentukan Badan Pengelola Perbatasan di

Daerah mempunyai tugas menetapkan kebijakan

program pembangunan perbatasan, menetapkan

rencana kebutuhan anggaran, mengoordinasikan pelaksanaan, dan melaksanakan evaluasi dan pengawasan terhadap pengelolaan batas wilayah negara dan kawasan perbatasan. Tugas BPPD Provinsi pada peraturan menteri yang baru sama dengan tugas BPPD Provinsi pada peraturan menteri sebelumnya.

Tabel 4.4.

Fungsi Badan Pengelola Perbatasan Provinsi

\begin{tabular}{|c|c|}
\hline $\begin{array}{l}\text { Peraturan Menteri Dalam Negeri Nomor } 2 \text { Tahun } \\
2011 \text { Tentang Pedoman Pembentukan Badan } \\
\text { Pengelola Perbatasan Di Daerah }\end{array}$ & 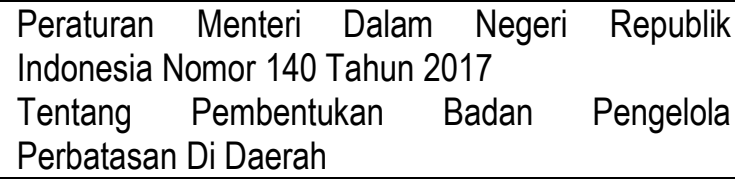 \\
\hline $\begin{array}{l}\text { Pasal } 10 \\
\text { (1) Penyusunan dan penetapan rencana aksi } \\
\text { pembangunan batas wilayah negara dan } \\
\text { kawasan perbatasan di provinsi; } \\
\text { (2) Pengoordinasian penetapan kebijakan dan } \\
\text { pelaksanaan pembangunan, pengelolaan } \\
\text { serta pemanfaatan batas wilayah negara } \\
\text { dan kawasan perbatasan di provinsi; } \\
\text { (3) Pengelolaan dan fasilitasi penegasan, } \\
\text { pemeliharaan dan pengamanan batas } \\
\text { wilayah negara di provinsi; } \\
\text { (4) Inventarisasi potensi sumber daya dan } \\
\text { rekomendasi penetapan zona } \\
\text { pengembangan ekonomi, pertahanan, } \\
\text { sosial budaya, lingkungan hidup dan zona } \\
\text { lainnya di kawasan perbatasan provinsi; } \\
\text { (5) Penyusunan program dan kebijakan } \\
\text { pembangunan sarana dan prasarana } \\
\text { perhubungan dan sarana lainnya di } \\
\text { kawasan perbatasan provinsi; } \\
\text { (6) Penyusunan anggaran pembangunan dan } \\
\text { pengelolaan batas wilayah negara dan } \\
\text { kawasan perbatasan sesuai dengan skala } \\
\text { prioritas di provinsi; dan } \\
\text { (7) Pelaksanaan, pengendalian dan } \\
\text { pengawasan serta evaluasi dan pelaporan } \\
\text { pelaksanaan pembangunan dan } \\
\text { pengelolaan batas wilayah negara dan } \\
\text { kawasan perbatasan di provinsi. }\end{array}$ & $\begin{array}{l}\text { Pasal } 11 \\
\text { (1) penyusunan rencana aksi pembangunan } \\
\text { kawasan perbatasan; } \\
\text { (2) Penyusunan program dan anggaran } \\
\text { pembangunan kawasan perbatasan } \\
\text { sesuai dengan skala prioritas; } \\
\text { (3) Pengoordinasian pelaksanaan } \\
\text { pembangunan dan pemanfaatan kawasan } \\
\text { perbatasan; penasan, } \\
\text { (4) Pelaksanaan fasilitasi penegasan, } \\
\text { pemeliharaan, dan pengamanan batas } \\
\text { wilayah negara; } \\
\text { (5) Penginventarisasian potensi sumber daya } \\
\text { untuk pengusulan penetapan zona } \\
\text { pengembangan ekonomi, sosial budaya, } \\
\text { lingkungan hidup, dan zona lainnya di } \\
\text { kawasan perbatasan; dan } \\
\text { (6) Pelaksanaan pengendalian dan } \\
\text { pengawasan serta evaluasi dan pelaporan } \\
\text { pelaksanaan pembangunan kawasan } \\
\text { perbatasan. }\end{array}$ \\
\hline
\end{tabular}


Perbedaan terletak pada bagian fungsi dari BPPD Provisi, perbedaan terlihat bahwa BPPD pada periode sebelumnya memiliki tugas yang lebih luas dari BPPD pada periode yang akan datang. Hilangnya fungsi penetapan rencana aksi dan pembangunan serta penyusunan program kebijakan pembangunan sarana dan prasana perhubungan merupakan bukti bahwa fungsi dari BPPD yang akan datang menjadi lebih sempit dan bersifat lebih umum. Menurut hemat penulis BPPD yang baru yang berdasar pada Peraturan Menteri Nomor 140 Tahun 2017 Tentang Pembentukan Badan Pengelola Perbatasan di Daerah bila dilihat dari kewenangan dan tupoksinya tidak dapat menjawab kendala serta hambatan yang dihadapi oleh BPPD sebelumnya. Fungsi yang semakin berkurang justru akan mempersulit kinerja dari BPPD, terlebih lagi masalah penetapan dan program kebijakan pembangunan sarana dan prasarana yang tentu sangat dibutuhkan dalam pengelolaan kawasan perbatasan terutama pada Provinsi Kepulauan Riau.

Peraturan perundang-undangan merupakan salah satu bagian dari politik hukum pemerintah yang sejatinya politik hukum merupakan alat untuk mencapai tujuan namun dalam pengelolaan perbatasan terkhusus didalam dimanika kelembagaan justru menambah kompleksitas permasalahan perbatasan yang telah ada. Apabila dikaitkat dengan teori politik hukum Syaukani dalam bukunya yang berjudul dasar-dasar politik hukum menginterpretasikan makna politik hukum yang disampaikan oleh Garuda nusantara menjadi beberapa konsep diantaranya: ${ }^{35}$
Pelaksanaan ketentuan hukum yang telah ada secara konsiten, didalam pengelolaan kawasan perbatasan dapat dinyatakan tidak adanya konsistensi dari pemerintah terhadap ketentuan hukum yang telah ada. Dimanika kelembagaan dari BPPD berubah menjadi Biro lalu berubah lagi menjadi BPPD merupakan bukti ketidak konsistenan pemerintah dalam membuat ketentuan hukum. Sejatinya ketentuan hukum ini harus konsisten agar dapat menyelesaikan permasalahan yang ada dengan optimal.

Pembangunan hukum yang intinya adalah pembaharuan terhadap ketentuan hukum yang telah ada dan dianggap usang, dan penciptaan ketentuan hukum yang diperlukan untuk memenuhi tuntutan perkembangan yang terjadi dalam masyarakat, didalam pengelolaan perbatasan dalam hal pembaharuan hukum telah dilakukan oleh pemerintah sebanyak dua fase dimana fase pertama dengan mengalihkan fungsi pengelolaan perbatasan dari Badan kepada Biro namun dan fase kedua dengan merubah mengalihkan kembali fungsi Biro kepada Badan. Pembaharuan ini sejatinya adalah untuk memenuhi tuntutan setra pencapaian tujuan pengelolaan perbatasan namun pada kenyataannya pembaharuan ini justru menambah kompleksitas permasalahan yang telah ada. Tuntutan dari awal terbentuknya BPPD adalah penguatan kelembagaan namun pembaharuan yang dilakukan hanya sebatas alih fungsi kelembagaan, kewenangannya tetap sama. Bahkan fungsinya justru berkurang. Menurut penulis hal ini tidak seuai dengan teori politik hukum yang ada sehingga pencapaian tujuan akan sulit dicapai.

35 Iman Syaukani.Loc.Cit. Hal. 23. 
58 Okky Razma \& Pery RS, Politik Hukum Pengelolaan Kawasan Perbatasan...

Penegasan fungsi lembaga penegak atau pelaksana hukum dan pembinaan anggotanya, berdasarkan poin ketiga teori politik hukum ini apabila dikaitkan dengan kelembagaan pengelolaan perbatasan maka penegasan fungsi dari kelembagaan belum tercapai. Selama dinamika kelembagaan yang terjadi fungsi kelembagaan BPPD tidak diperkuat justru berkurang, Fungsi yang penting sebagai koordinator yaitu terkait penetapan justru dihapus, tidak ada penegasan fungsi kelembagaan.

Meningkatkan kesadaran hukum masyarakat menurut persepsi kelompok elit pengambilan kebijakan, peningkatan kesadaran hukum masyarakat dimulai dari kesadaran hukum para penyelenggara negara. Penyelenggara negara dalam hal ini mempuyai wewenang untuk mengambil kebijakan. Kebijakan dalam pengelolaan kawasan perbatasan menurut penulis berdasarkan penelitian yang dilakukan belum maksimal. Pemerintah tidak jeli dalam mengambil kebijakan. Permasalahan kawasan perbatasan terutama Provinsi Kepulauan Riau lebih kepada permasalahan pokok di kawasan seperti pembenahan kawasan perbatasan, kesejahteraan masyarakat perbatasan, namun kebijakan selama ini lebih kepada dinamika kelembagan yang justru menambah kompleksitas dari permasalahan yang telah ada.

Pengelolaan kawasan perbatasan Provinsi Kepulauan Riau pada fokus penelitian penulis ini adalah lebih kepada aspek dimanika kelembagaan. Maka dalam hal ini akan penulis kaitkan juga dengan teori managemement yang telah disebutkan pada pembabahasan sebelumnya. Kegiatan administration/management dalam pengelolaan kawasan perbatasan dapat dilaksanakan secara overlapping dengan demarkasi. Hal ini didasarkan pada pertimbangan bahwa dalam kenyataannya seringkali dihadapi kendala dan dinamika yang terjadi di lapangan menyangkut aspek ekonomi, sosial, budaya dan politik yang kerap memerlukan adanya kerjasama bilateral antar kedua negara yang berbatasan di berbagai sektor tersebut. ${ }^{36}$

Berdasarkan teori tersebut maka pengelolaan kawasan perbatasan yang dihadapi oleh Provinsi Kepulauan Riau yaitu pada tahap management. Salah satu dari aspek management ini dalah terkait kelembagaan. Pengelolaan kawasan perbatasan memerlukan kelembagan yang terintegrasi agar pengelolaan dapat optimal. Salah satu unsur penting dalam mempertahankan kedaulatan negara terletak pada posisi kawasan perbatasan. Dalam kaitan dengan kajian terhadap batas wilayah negara, tidak dapat lepas dari aspek pengaruh aktivitas penyelenggaraan pemerintahan negara terhadap kawasan perbatasan. Hadirnya Badan Pengelola Perbatasan sebagai koordinator telah mengarah kepada integrasi dalam pengelolaan kawasan perbatasan namun dimanika kelembagaan pengelolaan perbatasan didaerah serta muatan dari politik hukum membuat managemen dalam pengelolaan perbatasan menjadi tidak optimal bahkan semakin kompleks.

36 Budi Hermawan B. Loc. Cit. Hal. 58. 


\section{Penutup}

\subsection{Kesimpulan}

Berdasarkan hasil pembahasan dari penelitian yang sudah penulis deskripsikan, maka penulis menarik kesimpulan dari penelitian ini yaitu bahwa politik hukum yang berada pada pengelolaan kawasan perbatasan di Provinsi Kepulauan Riau yang sejatinya untuk mencapai tujuan negara dalam hal ini belum terlaksana dengan optimal justru menambah rumit permasalahan perbatasan yang telah ada seperti dimamika kelembagaan, koordinasi yang lemah serta anggaran yang minim. Dinamika kelembagaan didaerah dalam pengelolaan kawasan perbatasan tidak sesuai dengan tujuan dari politik hukum, visi seta misi hadirnya BPPD. Menurut penulis dalam hal ini penyelenggara belum optimal dalam menjadikan politik hukum sebagai alat pencapaian tujuan terkhusus pada pengelolaan kawasan perbatasan.

\subsection{Saran}

Berdasarkan penelitian yang telah peneliti lakukan terhadap politik hukum pengelolaan kawasan perbatasan Provinsi Kepulauan Riau, peneliti memiliki saran yaitu seharusnya penyelenggara harus lebih jeli dalam merumuskan serta menjalankan rumusan dari politik hukum tersebut. Seharusnya pemerintah konsisten dalam menjalankan ketentuan hukum yang telah ada, jika ada pembaharuan maka pembaharuan tersebut harus sesuai dengan tuntutan yang mengerah pada pencapaian tujuan bukan menambah kompleksitas dari permasalahan yang telah ada. Penguatan kelembagaan lewat penguatan fungsi kelembagaan diperlukan didalam pengelolaan kawasan perbatasan.

\section{DAFTAR PUSTAKA}

\section{Buku}

Jusnadi, Achmad, Herie Saksono dan Suryo Sakti. Platform Penanganan Permasalahan Perbatasan Antarnegara. Jakarta: Direktorat Wilayah Administrasi dan Perbatasan, Direktorat Jenderal Permasalahan Umum, Departemen Dalam Negeri, 2005.

Mauna, Bour. Hukum Internasional: Pengertian, Peranan, dan Fungsi Dalam Era Dinamika Global, edisi ke 2. Bandung: Alumni, 2002.

Panama, A.N. Menjaga Indonesia Dari Kepri. Tanjungpinang: Badan Pengelola Perbatasan Provinsi Kepri, 2012.
S, Haris. Desentralisasi dan Otonomi Daerah. Jakarta: LIPPI Perss, 2007.

S.S, Hadiwijoyo. Batas Wilayah Negara Indonesia. Yogyakarta: Gava Media, 2008.

Soemitro. Metode Penelitian Hukum dan Jurimetri. Jakarta: Ghalia Indonesia, 1988.

Sunggono, B. Metode Penelitian Hukum, Bandung: Rajawali Pers. Bandung: Rajawali Pers, 2008.

Syaukani, Imam \& Ahsin Thohari. Dasar-dasar Politik Hukum. Jakarta: Rajawali Pers, 2013. 


\section{Artikel}

Adhayanto, Oksep. "Maritime Constitution." Jurnal Selat 2, No. 1 (2014): 135-145.

Hermawan, Budi Hermawan. "Konsepsi dan Pengelolaan Wilayah Perbatasan Negara: Perspektif Hukum Internasional." Tanjungpura Law Jurnal 1 (2016).

Irman \& Oksep Adhayanto. "Perlindungan Hukum Terhadap Wilayah Perbatasan di Provinsi Kepulauan Riau." Prosiding Seminar Bersama Program Studi Ilmu Hukum Fisip Umrah Dengan Fakultas Hukum Universitas Islam Riau. Tanjungpinang: Program Studi IImu Hukum Fakultas IImu Sosial dan IImu Politik Universitas Maritim Raja Ali Haji, 2016.

Panama, A.N. Menjaga Indonesia Dari Kepri. Tanjungpinang: Badan Pengelola Perbatasan Provinsi Kepri, 2012.

Purwaka, Tommy Hendra. "Tinjauan Hukum Laut Terhadap Wilayah Kesatuan Republik Indonesia." Mimbar Hukum, n.d.: 26.

Suharjo, Muhammad. "Pembentukan Peraturan Daerah Yang Responsif Dalam Mendukung Otonomi Daerah." Jurnal IImu Hukum, No. 10 (2014): 19.

\section{Peraturan Perundang-Undangan}

Undang-Undang Nomor 23 Tahun 2014 Tentang Pemerintahan Daerah

Undang-Undang Nomor 43 Tahun 2008 Tentang Wilayah Negara

Peraturan Presiden Republik Indonesia Nomor 12 Tahun 2010 Tentang Badan Nasional Pengelola Perbatasan

Peraturan Menteri Dalam Negeri Nomor 2 Tahun 2011 Tentang Pedoman Pembentukan Badan Pengelola Perbatasan Di Daerah

Peraturan Daerah Provinsi Kepulauan Riau Nomor 5 Tahun 2011 Tentang Organisasi Dan Tata Kerja Inspektorat, Badan

Perencanaan Pembangunan Daerah, Lembaga Teknis Daerah, Satuan Polisi Pamong Praja Dan Lembagab Lain Provinsi Kepulauan Riau

Peraturan Pemerintah Nomor 8 Tahun 2016 Tentang Perangkat Daerah

Peraturan Gubernur Kepulauan Riau Nomor 60 Tahun 2016 Tedntang Kedudukan, Susunan Organisasi, Tugas Dan Fungsi, Serta Tata Kerja Perangkat Daerah

Peraturan Menteri Dalam Negeri Nomor 140 Tahun 2017 Tentang Pembentukan Badan Pengelola Perbatasan di Daerah 